
ISSN : 2615-1995, E-ISSN : 2615-0654

J. Madani., Vol. 3, No. 2, September 2020 (196 - 201)

C2018 Lembaga Kajian Demokrasi

dan Pemberdayaan Masyarakat (LKD-PM)

DOI : https://doi.org/10.33753/madani.v3i2.116

\title{
Implementasi Standar Operasional Prosedur Penyelenggaraan Pendidikan di Lembaga Pembinaan Khusus Anak (LPKA) Tangerang
}

\author{
Lollong Manting \\ Fakultas Keguruan dan Ilmu Pendidikan, Universitas Pamulang \\ lollongmanting@gmail.com \\ Pantja Bambang Sudarwanto \\ Fakultas Keguruan dan Ilmu Pendidikan, Universitas Pamulang \\ dspap.fm@gmail.com
}

\begin{abstract}
Abstrak
Tujuan dari penelitian ini untuk mengetahui bagaimana penerapan atau implementasi standar operasional prosedur (SOP) penyelenggaraan pendidikan yang dilakukan di Lembaga Pembinaan Khusus Anak (LPKA) Tangerang sebagai salah satu instansi pemerintah yang berkewajiban untuk melakukan pembinaan terhadap anak yang berhadapan dengan hukum. Implementasi SOP penyelenggaraan pendidikan mengacu kepada peraturan Kementerian Pemberdayaan Aparatur Negara dan Reformasi Birokrasi (Kemenpan RB) Nomor 35 Tahun 2012 yang mengamanatkan tujuan dari SOP dalam konteks penyelenggaraan tugas dan fungsi aparat penyelenggara negara atau aparaur sipil negara harus memenuhi prinsip-prinsip dari SOP itu sendiri, antara lain, a) prinsip kemudahan dan kejelasan, b) prinsip efisien dan efektifitas, c) prinsip keselarasan, d) prinsip keterukuran, e) prinsip dinamis, f) prinsip yang berorientasi pada pengguna, g) prinsip kepatuhan hukum, dan h) prinsip kepastian hukum. Adapun metode riset yang yang digunakan dalam penelitian ini penelitian kualitatif, dengan tujuan untuk memahami sekaligus juga menginterpretasi gejala-gejala atau fenomenafenomena yang ada pada objek penelitian secara lebih detail. Adapun hasil penelitian berdasarkan riset yang dilakukan adalah bahwa penerapan SOP yang ada dapat dikatakan memenuhi prinsip-prinsip implementasi SOP. Sedangkan kesimpulan dari penelitian ini adalah bahwa LPKA Tangerang telah mengimplementasikan SOP yang ada dalam bidang penyelenggaraan pendidikan walaupun masih ada beberapa kekurangan dari segi pemenuhan beberap unsur pendukung seperti sarana dan prasarana, sumber daya manusia, dan anggaran yang terbatas, implementasi standar operasional prosedur penyelenggaraan pendidikan di LPKA Tangerang adalah perwujudan dari pemenuhan hak anak atas pendidikan yang dijamin oleh undang-undang.
\end{abstract}

Kata Kunci : Hak Anak, Pendidikan, Standar Operasional Prosedur, Lembaga Pembinaan Khusus Anak

\begin{abstract}
The purpose of this research is to find out how the implementation of standard operating procedures (SOP) for the application of education carried out at the Tangerang Special Child Treatment Institute (LPKA) as one of the government agencies that are obliged to provide guidance to children who are in conflict with the law. The implementation of SOP in the field of education refers to the regulations of the Ministry of Empowerment of the State Apparatus and Bureaucratic Reform (Kemenpan RB) No. 35 of 2012 which mandates the objectives of the SOP in the context of carrying out the duties and functions of the state administrators or state civilian apparatus, must fulfill the principles of the SOP itself, such as, a) the principle of ease and clarity, b) the principle of efficiency and effectiveness, $c$ ) the principle of harmony, d) the principle of measurement, e) the dynamic principle, $f$ ) the principle of user-oriented, $g$ ) the principle of legal compliance, and $h$ ) the principle legal certainty. The research method used in this study is qualitative research, with the aim of understanding as well as interpreting the
\end{abstract}


symptoms or phenomena that exist in the object of research in more detail. The results of the research conducted is that the application of existing SOPs can be said to meet the principles of SOP implementation. While the conclusion of this study is that LPKA Tangerang has implemented the existing SOPs in the field of education administration, although there are still some shortcomings in terms of fulfilling some supporting elements such as facilities and infrastructure, human resources, and limited budgets, implementation of operational standard procedures for providing education in LPKA Tangerang is an embodiment of the fulfillment of children's rights to education guaranteed by law.

Keywords : Child rights, Education, procedural operational standards, Special Child Treatment Institution

\section{PENDAHULUAN}

Harus diakui bahwa pendidikan merupakan avand-garde suatu bangsa. Pendidikan dalam skala yang menyeluruh akan sangat menentukan warna peradaban suatu bangsa, Suharto (2012: 5). Berdasarkan Undang-Undang Nomor 11 Tahun 2012 tentang Sistem Peradilan anak, anak yang berkonflik dengan hukum adalah Anak yang telah berumur 12 (dua belas) tahun tetapi belum berumur 18 (delapan belas) tahun yang diduga melakukan tindak pidana. Terkait dengan tindak pidananya itu, Anak kemudian harus berhadapan dengan Sistem Peradilan Pidana Anak. Sistem Peradilan Pidana pada hakikatnya identik dengan sistem penegakan hukum pidana atau sistem kekuasaan kehakiman di bidang hukum pidana. Sistem tersebut diimplementasikan dalam empat sub sistem kekuasaan yaitu, penyidikan, penuntutan, pengadilan dan pelaksanaan pidana. Sebagai sistem penegakan hukum pidana maka di dalam sistem peradilan terdapat aspek penegakan hukum pidana materil dan hukum pidana formal serta aspek penegakan hukum pelaksanaan pidana.

Dalam konteks Pemasyarakatan, Pemasyarakatan memiliki peranan penting yang sedikit berbeda dengan sistem peradilan pidana untuk orang dewasa. Sistem Pemasyarakatan berperan pada tahap pra adjudikasi, adjudikasi dan post adjudikasi. Perlindungan Anak tersebut dilakukan dengan mempertimbangkan kepentingan yang terbaik bagi Anak, di mana Anak adalah subjek dengan kebutuhan khusus dan berhak akan masa depan yang lebih baik, sehingga menempatkan Anak kembali kepada keluarga dan masyarakatnya adalah hal yang sejalan dengan filosofi Sistem Pemasyarakatan yang bertujuan untuk mengintegrasikan kembali pelaku kejahatan kepada masyarakat.

Ketika Undang-undang Nomor 11 Tahun 2012 Tentang Sistem Peradilan Pidana Anak telah diberlakukan secara serentak di seluruh Indonesia pada tahun 2014, dalam dalam jangka waktu empat tahun sejak diberlakukannya ada beberapa data yang dapat mengindikasikan bahwa dorongan perubahan perspektif dalam penanganan Anak ini sudah mulai menapaki kemajuan, jika dibandingkan dengan 4 tahun sebelum diberlakukannya UU SPPA, seperti tergambar pada tabel di bawah ini:

Tabel 1. Data Jumlah Anak dalam LPKA / Lapas 2012-2015

\begin{tabular}{|c|c|c|}
\hline No & Tahun & Jumlah Anak dalam Lapas / LPKA \\
\hline 1 & 2012 & 3.657 \\
\hline 2 & 2013 & 3.466 \\
\hline 3 & 2014 & 2.643 \\
\hline 4 & 2015 & 2.056 \\
\hline \multicolumn{3}{|c|}{ Sumber data: Sistem Data Base Pemasyarakatan 2020 } \\
\hline
\end{tabular}

Berdasarkan Tabel.1 di atas tergambar bahwa pada 2012 Jumlah anak yang berada dalam LPKA adalah 3.657 anak, dan pada tahun berikutnya yaitu pada tahun 2013 sebanyak 3.466 anak, tahun 2014 mengalami penurunan menjadi 2.643, dan pada tahun 2015 jumlah anak dalam lembaga mengalami penurunan lagi menjadi 2.056 anak.

Tabel 2. Data Jumlah Anak dalam LPKA/ Lapas 2016-2020

\begin{tabular}{|c|c|c|}
\hline No & Tahun & Jumlah Anak dalam Lapas / LPKA \\
\hline 1 & 2016 & 2,188 \\
\hline 2 & 2017 & 2,835 \\
\hline 3 & 2018 & 2,364 \\
\hline 4 & 2019 & 2,026 \\
\hline 5 & Juni 2020 & 1,448 \\
\hline \multicolumn{3}{|c|}{ Sumber data: Sistem Data Base Pemasyarakatan 2020 } \\
\hline
\end{tabular}

Pada Tabel 2 juga tergambar bahwa dalam kurun waktu 5 (lima) tahun terakhir jumlah anak 
yang berada dalam Lembaga Pembinaan Khusus Anak atau yang masih ditempatkan di Lembaga Pemasyarakatan Umum mengalami dari segi jumlah turun naik, misalnya pada tahun 2016 jumlah anak dalam lembaga adalah 2.188 anak, pada tahun 2017 mengalami peningkatan menjadi 2.835 , pada tahun 2018 , angkanya menurun lagi menjadi 2.364 anak, dan pada tahun 2019, jumlahnya semakin menurun menjadi 2.026 , dan terakhir pada tahun 2020 bulan Juni, jumlah anak berada pada angka paling rendah yaitu sebanyak 1.448 anak.

Berdasarkan perbandingkan tersebut dapat dikatakan bahwa dalam lima tahun terakhir jumlah anak yang melakukan tindak pidana semakin menurun, dan tentunya tidak terlepas dari diberlakukannya UU SPPA yang diiringi dengan adanya upaya serius dari semua komponen masyarakat serta aparat penegak hukum untuk mengedepankan kepentingan terbaik buat anak.

Dengan diberlakukannya Undang-undang SPPA ini, maka Pemasyarakatan sekaligus juga dituntut untuk semakin mempersiapkan diri. Peran Lembaga Pembinaan Khusus Anak (LPKA) sebagai salah satu Unit Pelaksana Teknis Pemasyarakatan menjadi sangat penting dalam mendorong penanganan perkara Anak melalui pendekatan keadilan restoratif dan diversi serta program dan kegiatan pembinaan anak yang dapat menjadi modal besar bagi anak setelah menjalani pidana di dalam lembaga. Keberadaan regulasi baru ini menuntut Instansi Pemasyarakatan untuk mempersiapkan kebutuhan-kebutuhan terkait implementasi Undang-undang tersebut, baik dalam hal ketentuan operasional yang lebih rinci maupun dari segi perencanaan dan penganggaran, sumber daya manusia, maupun sarana dan prasarana.

Pelaksanaan pendidikan di dalam LPKA adalah salah satu kewajiban negara dalam hal ini Kementerian Hukum dan Hak Asasi Manusia yang diamanatkan dalam UU SPPA di mana dalam penyelenggaraan pendidikan tersebut mengacu kepada berbagai macam regulasi yang terkait, salah satunya adalah standar operasional prosedur pelaksanaan pendidikan yang menjadi acuan atau pedoman petugas LPKA dalam menyelenggarakan pendidikan.

Berdasarkan uraian di atas, maka penulis tertarik untuk meneliti bagaimana penerapan atau implementasi standar operasional prosedur pendidikan yang dilakukan di Lembaga Pembinaan Khusus Anak (LPKA) Tangerang, dengan judul "Implementasi Standar Operasional Prosedur Penyelenggaraan Pendidikan di Lembaga Pembinaan Khusus Anak (LKPA) Tangerang".

\section{METODE}

Pendekatan yang digunakan dalam penelitian ini adalah kualitatif, menurut Moleong (2017: 6) Penelitian kualitatif adalah penelitian yang bermaksud untuk memahami fenomena tentang apa yang dialami oleh subjek penelitia, misalnya perilaku, persepsi, motivasi, tindakan dan lainnya secara holistic, dan dengan cara deskriptif dalam bentuk narasi dan bahasa yang dilakukan melalui observasi dan wawancara, pada suatu konteks khusus yang alamiah dan dengan memanfaatkan berbagai metode alamiah. Menurut Sugiono (2011: 224) Observasi atau pengamatan adalah prosedur pengumpulan data yang dilakukan dengan tektik pengumpulan data menjelaskan teknik pengumpulan data adalah langkah yang paling strategis dalam penelitian, karena tujuan utama dari penelitian adalah mendapatkan data secara ilmiah.

Sedangkan menurut Denzim dan Lincoln (2017: 5) mengemukakan bahwa penelitian kualitatif adalah penelitian yang menggunakan latar alamiah, dengan maksud menafsirkan fenomena yang terjadi dan dilakukan dengan jalan melibatkan metode yang ada.

Metode penelitian yang digunakan pada studi ini adalah metode jenis penelitian phenomenology. Phenomenology merupakan penelitian yang mengkhususkan pada fenomena dan realitas yang tampak untuk mengkaji penjelasan di dalamnya. Phenomenology sendiri memiliki dua makna yaitu sebagai filsafat sains dan juga metode penelitian, yang bertujuan mencari arti atau makna dari pengalaman yang ada dalam kehidupan.

Penelitian ini menggunakan jenis penelitian deskriptif, penelitian deskriptif merupakan 
data yang dikumpulkan adalah berupa kata-kata, gambar, dan bukan berupa angka-angka. Penelitian deskriptif berusaha memberikan gambaran secara sistematis dan cermat fakta-fakta aktual dan sifat populasi tertentu. Secara spesifik, penelitian deskriptif memiliki ciri-ciri sebagai berikut:

1. Bertujuan untuk memecahkan masalah-masalah aktual yang dihadapi sekarang.

2. Bertujuan untuk mengumpulkan data atau informasi untuk disusun, dijelaskan dan dianalisis.

Jenis penelitian secara deskriptif ini dilakukan dengan alasan penelitian ini data berupa kata-kata (bukan angka) yang bersumber dari observasi, wawancara, catatan laporan, dokumen, dan lain-lain atau dengan kata lain penelitian ini berusaha mendeskripsikan suatu gejala, peristiwa, dan kejadian saat sekarang dengan maksud memperoleh data yang berbentuk kata, kalimat, skema, gambar dan akan dijabarkan dengan angka sebagai sajian penguat lalu di implimentasikan hasil penelitian berupa katakata sebagai penjabaran hasil penelitian tentang penerapan SOP di LPKA Tangerang.

\section{HASIL dan PEMBAHASAN}

Peraturan Kementerian PAN dan RB No. 35 tahun 2012 tentang Pedoman penyusunan Standar Operasional Prosedur (SOP) mendefinisikan Standar Operasional Prosedur adalah serangkaian instruksi tertulis yang dibakukan mengenai berbagai proses penyelenggaraan aktivitas organisasi, bagaimana dan kapan harus dilakukan, dimana dan oleh siapa dilakukan.

SOP sebagai suatu dokumen/instrumen memuat tentang proses dan prosedur suatu kegiatan yang bersifat efektif dan efisisen berdasarkan suatu standar yang sudah baku. Standar internal yang bersifat prosedural inilah yang disebut dengan Standar Operasional Prosedur (SOP). Dilihat dari fungsinya, SOP berfungsi membentuk sistem kerja \& aliran kerja yang teratur, sistematis, dan dapat dipertanggungjawabkan; menggambarkan bagaimana tujuan pekerjaan dilaksanakan sesuai dengan kebijakan dan peraturan yang berlaku; menjelaskan bagaimana proses pelaksanaan kegiatan berlangsung; sebagai sarana tata urutan dari pelaksanaan dan pengadministrasian pekerjaan harian sebagaimana metode yang ditetapkan; menjamin konsistensi dan proses kerja yang sistematik; dan menetapkan hubungan timbal balik antar Satuan Kerja.

Sebagai suatu instrumen manajemen, SOP berlandaskan pada sistem manajemen kualitas (Quality Management System), yakni sekumpulan prosedur terdokumentasi dan praktek-praktek standar untuk manajemen sistem yang bertujuan menjamin kesesuaian dari suatu proses dan produk (barang dan/atau jasa) terhadap kebutuhan atau persyaratan tertentu. Sistem manajemen kualitas berfokus pada konsistensi dari proses kerja. Hal ini mencakup beberapa tingkat dokumentasi terhadap standar-standar kerja. Sistem ini berlandaskan pada pencegahan kesalahan, sehingga bersifat proaktif, bukan pada deteksi kesalahan yang bersifat reaktif. Secara konseptual, SOP merupakan bentuk konkret dari penerapan prinsip manajemen kualitas yang diaplikasikan untuk organisasi pemerintahan (organisasi publik). Oleh karena itu, tidak semua prinsip-prinsip manajemen kualitas dapat diterapkan dalam SOP karena sifat organisasi pemerintah berbeda dengan organisasi privat. Salah satu upaya penataan tata laksana diwujudkan dalam bentuk penyusunan dan implementasi standar Standar Operasional Prosedur Administrasi Pemerintahan (selanjutnya disebut dengan SOP AP). Standar Operasional Prosedur adalah serangkaian instruksi tertulis yang dibakukan mengenai berbagai proses penyelenggaraan aktivitas organisasi, bagaimana dan kapan harus dilakukan, dimana melakukannya dan siapa yang melakukan.

Adapun Format SOP AP yang dipersyaratkan dalam Kebijakan Reformasi Birokrasi memiliki format yang telah distandarkan dan tidak seperti format SOP pada umumnya. Adapun format SOP AP yang dipergunakan dalam Kebijakan Reformasi Birokrasi adalah Format Diagram Alir Bercabang (Branching Flowcharts) dan tidak ada format lainnya yang dipakai. Hal ini diasumsikan bahwa prosedur pelaksanaan tugas dan fungsi 
instansi pemerintah termasuk di dalamnya Kementerian/Lembaga dan Pemerintah Daerah memuat kegiatan yang banyak (lebih dari sepuluh) dan memerlukan pengambilan keputusan yang banyak.

Sedangkan berdasarkan Peraturan Menteri Negara Pendayagunaan Aparatur Negara Nomor: PER/35/M.PAN/11/2012 tentang Pedoman Penyusunan Standar Operating Prosedur Administrasi Pemerintahan, penyusunan SOP harus memenuhi prinsip-prinsip sebagai berikut:

a. Prinsip kemudahan dan Kejelasan

b. Prinsip Efisien dan Efektifitas

c. Prinsip Keselarasan

d. Prinsip Keterukuran

e. Prinsip Dinamis

f. Prinsip berorientasi pada pengguna (mereka yang dilayani)

g. Prinsip Kepatuhan Hukum

h. Prinsip Kepastian Hukum

\section{Hasil}

Hasil peneelitian yang dilakukan di Lembaga Pembinaan Khusus Anak (LPKA) Tangerang, diketahui bahwa terdapat enam belas (16) standar operasional prosedur (SOP) penyelenggaraan pendidikan untuk anak yang berada dalam Lembaga, enam belas SOP tersebut adalah sebagai berikut :

1. SOP Pemanggilan Peserta Didik.

2. SOP Pendataan Anak sebagai Peserta Didik.

3. SOP Pengumpulan Berkas Anak.

4. SOP Pengkalisifikasian Peserta Didik.

5. SOP Pengusulan Nomor Induk Sebagai Peserta Didik.

6. SOP Persiapan Perlengkapan Belajar.

7. SOP Pengeluaran Anak yang mengikuti Ujian di Luar LPKA.

8. SOP Perencanaan Model Belajar.

9. SOP Persiapan Pelaksanaan Model Belajar di Luar LPKA.

10. SOP Pelaksanaan Model Belajar di Luar LPKA.

11. SOP Persiapan Pelaksanaan Model Belajar di Dalam LPKA.

12. SOP Pelaksanaan Model Belajar di Dalam LPKA.
13. SOP Pelaksanaan Model Belajar Melalui Bedah Buku.

14. SOP Pelaksanaan Model Belajar Melalui out bond.

15. SOP Pelaksanaan Model Belajar Melalui e-learning.

16. SOP Pelaksanaan Model Belajar Melalui Diskusi Kelompok.

\section{Pembahasan}

Berdasarkan hasil penelitian yang dilakukan di lapangan, maka dapat dikatakan bahwa enam belas SOP yang berkaitan dengan penyelenggaraan pendidikan telah memenuhi prinsip-prinsip SOP sesuai dengan yang digariskan dalam Permenpan Nomor 35 Tahun 2012.

a. Prinsip kemudahan dan Kejelasan

SOP yang ada membakukan prosedur pelaksanaan tugas dan fungsi setiap petugas LPKA sehingga lebih mudah dimengerti dan diterapkan oleh semua pegawai, termasukjika ada pegawai baru yang harus melaksanakan tugas tersebut.

b. Prinsip Efisien dan Efektifitas

Prosedur-prosedur yang distandarkan dalam bentuk SOP merupakan prosedur yang paling efisien dan efektif dalam pelaksanaaan tugas pegawai.

c. Prinsip Keselarasan

Prosedur-prosedur yang distandarkan memiliki kesesuain dan keselaran dengan prosedur-prosedur lain yang terkait.

d. Prinsip Keterukuran

Prosedur-prosedur yang distandarkan memiliki output yang dapat diukur secara rasional, terutama dari capaian sebuah SOP.

e. Prinsip Dinamis

Prosedur-prosedur yang distandarkan dapat disesuaikan dengan kebutuhan dan perkembangan di lapangan.

f. Prinsip berorientasi pada pengguna (mereka yang dilayani).

Prosedur-prosedur yang distandarkan memang menitikberatkan pada kepentingan yang terbaik buat yang berada dalam LPKA

g. Prinsip Kepatuhan Hukum

Prosedur-prosedur yang distandarkan ada- 
lah terjemahan secara lebih teknis dan operasional dari aturan yang lebih tinggi.

h. Prinsip Kepastian Hukum

Semua prosedur yang distandarkan ditetapkan oleh pimpinan sebagai sebuah produk hukum yang mengikat dan harus ditaati, dilaksanakan secara konsisten, dan menjadi isntrumen untuk melindungi pegawai dari kemungkinan tuntutan hukum dalam pelaksanaan tugasnya.

\section{SIMPULAN}

Berdasarkan hasil penelitian yang dilakukan, penulis dapat mengatakan bahwa penerapan SOP penyelenggaran pendidikan pada Lembaga Pembinan Khusus Anak (LKPA) Tangerang telah memenuhi prinsip-prinsip penyusunan SOP. Walaupun demikian ada beberapa catatan penting yang menjadi kendala dalam penerapan SOP tersebut, seperti keterbataan sarana dan prasarana yang dibutuhkan untuk melaksanakan semua SOP yang ada sedangkan seperti diketahui bahwa sarana dan prasarana adalah pendukung utama terlaksannya SOP secara maksimal, kendala berikutnya adalah keterbatasan sumber daya manusia yang sesuai dengan kebutuhan LPKA masih jauh dari yang diharapkan, pemenuhan pegawai atau petugas yang memiliki latar pendidikan, psikologi, dan lainnya, seharusnya menjadi perhatian penting dalam rekruitmen pegawai di LPKA.

Yang terakhir adalah kurang optimalnya pengawasan sehingga perlu adanya pelaksanaan monitoring dan evaluasi yang lebih intensif terhadap penerapan SOP di LPKA Tangerang untuk mengetahui dan memastikan bagaimana penerapannya di lapangan, sehingga dengan demikian dapat dilakukan berbagai perbaikan ke depan untuk kepentingan yang terbaik buat anak.

\section{PENGHARGAAN}

Terima kasih kami sampaikan kepada Kementerian Riset, Teknologi dan Pendidikan Tinggi atas dukungan yang diberikan, Kepala Lembaga Pembinaan Khusus Anak (LPKA) Tangerang beserta jajarannya, Dekan Fakultas Keguruan dan
Ilmu Pendidikan Universitas Pamulang dan Ketua Program Studi Pendidikan Ekonomi Universitas Pamulang.

\section{DAFTAR PUSTAKA}

Denzin and Lincoln. (2017). Handbook of Qualitative Research. Yogyakarta: Pustaka Pelajar.

Moleong, L. J. (2017). Metode Penelitian Kualitatif. Bandung: Remaja Rosdakary.

Silalahi, U..2012. Metode Penelitian Sosial. Cetakan Ketiga. Bandung: PT. Refika Aditama.

Sugiyono. (2011). Metode Penelitian Kuantitatif, Kualitatif dan R\&D. Bandung: Afabet.

Suharto, T. (2012). Pendidikan Berbasis Masyarakat. Cetakan kesatu. Yogyakarta: PT. Lkis Printing Cemerlang.

Peraturan Menteri Pendayagunaan Aparatur Negara dan Reformasi Birokrasi Republik Indonesia Nomor 35 tahun 2012 Tentang Pedoman Penyusunan Standar Operasional Prosedur Administrasi Pemerintahan.

Peraturan Menteri Negara Pendayagunaan Aparatur Negara dan Reformasi Birokrasi Nomor 20 Tahun 2010 Tentang Road Map Reformasi Birokrasi 2010-2014.

Peraturan Menteri Hukum dan Hak Asasi Manusia Nomor Tahun 2009 Tentang Cetak Biru Pembaharuan Pemasyarakatan.

Peraturan Menteri Hukum dan Hak Asasi Manusia Nomor Tahun 2018 Tentang Revitalisasi Pemasyarakatan.

Undang-Undang Republik Indonesia Nomor 8 Tahun 1981 Tentang Hukum Acara Pidana.

Undang-Undang Nomor 12 tahun 1999 tentang Pemasyarakatan.

Undang-undang Nomor 11 Tahun 2012 Tentng Sistem Peradilan Pidana Anak. 